\title{
Board 91: Research Initiation: A Study on the Intersection of Race and Gen- der on Leadership Formation of Engineering Students
}

\section{Prof. Carmen Maria Lilley, University of Illinois, Chicago}

Dr. Lilley's research interests in engineering education focus on professional development of engineering students at the undergraduate and graduate level. In particular, she is interested in the nuances of how the intersection of race/ethnicity with gender affects professional development in the area of leadership and the long term career trajectory of an individual. Her other research interests are focused on syntheses of low dimensions materials and the characterization and modeling of their material properties. 


\section{Research Initiation: A Study on the Intersection of Race and Gender on Leadership Formation of Engineering Students}

This NSF sponsored research initiation project explores the leadership beliefs, experiences, and knowledge/skills of undergraduate engineering students who have self-identified as having leadership experience and that a Research I minority serving institution for Asian Americans and Native Americans, as well as a Hispanic Serving Institution. Undergraduate engineering students with self-identified leadership experience were recruited from the college of engineering across the various majors. These students were interviewed one-on-one by the principal investigator using a semi-structured interview guide. The students were probed on their beliefs of leader attributes, their personal leader role models, their experiences in leadership roles, and how they viewed their skills as leaders. The research was approved by the institutional review board and all students signed a written consent prior to participation. The interviews took 60-90 minutes and included 32 questions. In total, 32 students were interviewed for this project with a mean age of 22.1 years (range: 18-34 years). There were 4 Bioengineering, 3 Civil Engineering, 6 Chemical Engineering, 5 Computer Science, 3 Electrical Engineering, 4 Industrial Engineering, and 7 Mechanical Engineering students. There were 15 men, 15 women and 2 transgender individuals. The study included 9 Asian, 9 White, 4 Black/African American, 7 Hispanic/Latino, and 3 Multiracial students.

The theoretical framework for the analysis was to use intersectionality, where a voice approach using race/ethnicity and gender as the social groups was applied to probe leadership development of undergraduate engineering students. [2-4] The focus was to collect narratives that elicited differences in perspectives within social subgroups that are outside of the norm (i.e. a White male) for engineering professions. Thus, questions for the interview guide were developed in consultation with two social scientists with expertise on race and gender; as well as consulting two underrepresented minority undergraduate engineering students, one male and one female, who were leaders in their engineering societies and who did not take part in the study. The coding of the interviews was done by the principal investigator. The first transcript was coded by the principal investigator and the social scientists were in consensus with the initial codes. The interviews were structured around three themes: 1) Who are leaders (society, technology, etc.) and what are their attributes? 2) What inspired the engineering undergraduate student to take on leadership roles and the lessons learned and/or skills developed from these experiences? Their self-selected social identities (e.g. race, gender, socioeconomic, etc.) and whether/how these identities influenced their experiences as leaders.

Using Grounded Theory by Charmaz [5], the interviews were coded line-by-line using gerunds and the constant comparative method was used to develop a code book during the focused coding phase [5]. From the focused coding, constructs, i.e. categories, of prototypical and antiprototypical leader attributes have been defined and personal role models of leaders have been preliminarily developed. Analytical memos were also being concurrently maintained during the coding processes. Axial coding, again using intersectionality and more specifically an intercategory approach [6], will be done after the focused coding is completed for all of the themes discussed in the interviews.

The outcomes of these analyses will be to develop three preliminary models on: 1) prototypical and anti-prototypical leaders for millennial undergraduate engineering students.

2) A model on how race/ethnicity and gender influence leadership experiences of undergraduate 
engineering students. 3) A model on how race/ethnicity and gender influence the skills and knowledge gaps of undergraduate engineering student's leadership development. These models will be used as the basis for comparing skills/knowledge millennial engineering student leaders have gained through the course of their education; and serve as the foundation for future research on developing interventions to address leadership development for a broad and diverse community of current and future undergraduate engineering students. Additional research will focus on how the leadership views of millennial engineering students may influence their expectations when joining the engineering profession, and whether there is an impact on their short to long term retention and leadership ascension during their careers.

Prototypical leader categories are discussed in a work in progress ASEE submission and thus not included here. The preliminarily categories for anti-prototypical leader attributes and personal leader role models are defined and discussed in Tables 1 and 2 respectively. Preliminary axial coding was performed using an intercategorical analysis is ongoing. However, early analysis indicates that the role models for students within intercategories of social groups were varied. In general, a majority of students had a role model when they were young and included role models from middle school through high school and college or having to take on an elder role (e.g. sibling and/or parent caretaker) when they were young. In addition, some of the lessons learned from their leadership roles have had positive effects on their professional development as engineers by gaining experiential knowledge. There is still a wealth of data that needs to be categorized and defined including skills/knowledge acquired, lingering gaps in skills/knowledge, and how intercategories have influenced their experiences.

Table 1. Anti-Prototypical Characteristics of a Leader

\begin{tabular}{|l|l|}
\hline Category & Definition \\
\hline Inept & $\begin{array}{l}\text { A leader who is unable to read social cues from a group. A person that is off } \\
\text { putting to the team or group. This person can be offensive unintentionally } \\
\text { because of lack of social awareness and cultural norms. }\end{array}$ \\
\hline Managing & $\begin{array}{l}\text { A leader who only looks at deadlines and tasks assignment. This person } \\
\text { focuses on meeting tasks without considering team needs, establishing } \\
\text { higher goals, foreseeing problems before they arise, planning ahead, lacking } \\
\text { vision, etc. This leader dictates work assignments without input of team or } \\
\text { knowing/understanding the skills within a team. }\end{array}$ \\
\hline Quitting & $\begin{array}{l}\text { A leader who gives up on a goal when faced with challenges or opposition. } \\
\text { A leader who will eventually give up on their efforts to achieve a desired } \\
\text { goal or ambition. }\end{array}$ \\
\hline Blaming others & $\begin{array}{l}\text { A leader who does not take responsibility for self or the team. The leader } \\
\text { will place blame on others for failures instead of accepting the own errors, } \\
\text { limitations or poor performance. }\end{array}$ \\
\hline Unknowing & $\begin{array}{l}\text { A leader that is not academically or technically prepared to solve problems, } \\
\text { lacks the necessary knowledge. A leader who is also unwilling to learn, } \\
\text { either through additional education or by learning from the team. A leader } \\
\text { who has the wrong solutions to problems or challenges. }\end{array}$ \\
\hline Bullying & $\begin{array}{l}\text { A leader who behaves in a way that set the standards of unacceptable } \\
\text { behavior for the team. A leader that creates a negative work environment } \\
\text { due to aggression, disrespectful behavior, or punishing/threatening actions. } \\
\text { This person may diminish the self-worth of others through bullying and } \\
\text { creates a hostile work environment. }\end{array}$ \\
\hline
\end{tabular}




\begin{tabular}{|l|l|}
\hline Cheating & $\begin{array}{l}\text { A leader who does not have integrity. This leader lies or is unethical in } \\
\text { order to succeed. }\end{array}$ \\
\hline Being selfish & $\begin{array}{l}\text { This leader only focuses on their own needs and takes credit for others } \\
\text { work. The leader uses other's contributions/efforts to get ahead without } \\
\text { acknowledging the contributions of others. }\end{array}$ \\
\hline $\begin{array}{l}\text { Being } \\
\text { emotional }\end{array}$ & $\begin{array}{l}\text { A leader who angers easily or becomes negative when faced with } \\
\text { difficulties. This leader cannot control emotional reactions to difficult } \\
\text { situations. }\end{array}$ \\
\hline Being arrogant & $\begin{array}{l}\text { A leader who fails to realize personal limitations of knowledge or strength. } \\
\text { This leader believes they know all the answers and are always right/correct } \\
\text { even when wrong. This leader will not apologize when wrong, because they } \\
\text { do not believe they should have to apologize. }\end{array}$ \\
\hline Being chaotic & $\begin{array}{l}\text { A leader who lacks organization. Can appear to take random actions or } \\
\text { make illogical decisions. }\end{array}$ \\
\hline $\begin{array}{l}\text { Lacking } \\
\text { Communication }\end{array}$ & $\begin{array}{l}\text { A leader who fails to communicate clearly to the team, group, or broad } \\
\text { audience. }\end{array}$ \\
\hline Discouraging & A leader who induces a loss of hope or diminishes ambition in others. \\
\hline
\end{tabular}

Table 2. Leader Role-Model Categories

\begin{tabular}{|c|c|}
\hline Scientist & $\begin{array}{l}\text { Scientists in fields such as physics that had notable achievements in their fields } \\
\text { of studies. }\end{array}$ \\
\hline $\begin{array}{l}\text { Current } \\
\text { Leaders in } \\
\text { Technology }\end{array}$ & $\begin{array}{l}\text { Elon Musk (b. 1971, Generation X), Bill Gates (b. 1955, Baby Boomer), Mark } \\
\text { Zuckerberg (b. 1984, Millennial). Both male and female students across } \\
\text { race/ethnicity only identified current technology leaders that are white males. } \\
\text { Elon Musk came up consistently in interviews because of his innovation and } \\
\text { also serving society by using technology to address societal needs. Bill Gates } \\
\text { came up for his service to society to improve societal conditions (e.g. global } \\
\text { health and Gates scholars for low income students). }\end{array}$ \\
\hline Parents & $\begin{array}{l}\text { Mother or Father who were the primary caretakers and serve as an example of } \\
\text { strong work ethics, risk taking and success. Parent(s) that took risks, such as } \\
\text { immigrating to US to begin a career or seek a better life, starting their own } \\
\text { business. Parent(s) that worked hard to endure economic hardship. }\end{array}$ \\
\hline & $\begin{array}{l}\text { Similar role model as a parent. They are role models of people that took risks } \\
\text { such as starting their own business and were successful. }\end{array}$ \\
\hline $\begin{array}{l}\text { Club } \\
\text { Leaders }\end{array}$ & $\begin{array}{l}\text { Cub Scouts and Girl Scouts organization provided opportunities to be leaders } \\
\text { within their packs or troops. The club leaders established the expectations and } \\
\text { gave the students the opportunity to organize and run their own events. Students } \\
\text { had to learn to work with peers, those above them in leadership roles, those they } \\
\text { saw as authorities (other parents) and those younger than them. }\end{array}$ \\
\hline Arti & $\begin{array}{l}\text { Movie directors Guillermo Del Toro and Robert Rodriguez, Rian Johnson were } \\
\text { mentioned. Musical artists, such as an orchestra conductor. The movie directors } \\
\text { were inspiring because they create the vision of a story and how it is } \\
\text { communicated, despite whatever controversy may arise from their vision and } \\
\text { implementation. Also, in the example of Del Toro and Rodriguez, there was a } \\
\text { strong tie to being of the same cultural background and seeing how Del Toro } \\
\text { gives back to his community by sponsoring education. For the orchestra } \\
\text { director, the ability of how a conductor leads individuals with their own } \\
\text { interpretation and style to play under the conductor's visions in a cohesive way }\end{array}$ \\
\hline
\end{tabular}




\begin{tabular}{|c|c|}
\hline & (i.e. guiding individuals to a common goal as set by the conductor). \\
\hline Siblings & $\begin{array}{l}\text { An older sibling who took the time to act as a caretaker. The older sibling was } \\
\text { the responsible leader of the sibling(s) in the family. }\end{array}$ \\
\hline $\begin{array}{l}\text { Self- } \\
\text { Identified }\end{array}$ & $\begin{array}{l}\text { A self-identified elder or caretaker of the family including siblings or parents. } \\
\text { The student took on responsibility to be a primary caretaker of a younger } \\
\text { sibling. As the elder, they also took on mentoring roles to guide their siblings on } \\
\text { to career pathways and encouraged them to study math, science and engineering. } \\
\text { On example was overcoming homelessness and providing stability and } \\
\text { mentoring to younger siblings on their career pathways. A number focused on } \\
\text { guiding siblings to focus on math, science, and engineering as a way to achieve } \\
\text { career success in any field. }\end{array}$ \\
\hline Coaches & $\begin{array}{l}\text { Athletic coaches that trained a team and also selected the peer leaders (captains) } \\
\text { of the team. They required students to work towards physical standards of } \\
\text { expectations and expected strong work ethic from the students. Some inspired } \\
\text { the students by helping them achieve success through positive training feedback } \\
\text { and setting positive expectations. A good coach was better than a coach that } \\
\text { belittled a student to improve their performance on a team. }\end{array}$ \\
\hline $\begin{array}{l}\text { Religious } \\
\text { Figures }\end{array}$ & $\begin{array}{l}\text { God, Jesus, and Mohammed were all mentioned as leaders. The tenants from } \\
\text { these figures were used as guiding lessons or support towards their ambitions. } \\
\text { They learn about leadership using lessons from these figures. }\end{array}$ \\
\hline Educators & $\begin{array}{l}\text { Teachers in high school or at the undergraduate level. These teachers were seen } \\
\text { as knowledgeable and also served as advisors and mentors to the students. }\end{array}$ \\
\hline $\begin{array}{l}\text { Political } \\
\text { Figures }\end{array}$ & $\begin{array}{l}\text { Obama was mentioned the most because of his perseverance, "going beyond the } \\
\text { hatred that was directed at him," being a strong communicator, having charisma } \\
\text { or mystique. Obama was also seen to have empathy and being open to hearing } \\
\text { out the opposing views. He was active in reaching out in communication to } \\
\text { those that both supported him and were opposed to him. Justin Trudeau was also } \\
\text { identified for being young and being able to empathize with the younger } \\
\text { generation. Other examples were women dictator who rose to control during a } \\
\text { time when women were not allowed to be part of politics. }\end{array}$ \\
\hline $\begin{array}{l}\text { Community } \\
\text { Trailblazers }\end{array}$ & $\begin{array}{l}\text { Leaders that fit within a self-identified social group or community that inspired } \\
\text { others because of their accomplishments, such as the founder of NSBE or } \\
\text { Michelle Obama. }\end{array}$ \\
\hline
\end{tabular}

[1] E. S. Ng, L. Schweitzer, and S. T. Lyons, "New generation, great expectations: A field study of the millennial generation," Journal of Business and Psychology, vol. 25, no. 2, pp. 281$292,2010$.

[2] K. Crenshaw, "Demarginalizing the intersection of race and sex: A black feminist critique of antidiscrimination doctrine, feminist theory and antiracist politics," U. Chi. Legal F., p. 139, 1989.

[3] B. Hooks, Talking back: Thinking feminist, thinking black. South End Press, 1989.

[4] H. Y. Choo and M. M. Ferree, "Practicing intersectionality in sociological research: A critical analysis of inclusions, interactions, and institutions in the study of inequalities," Sociological theory, vol. 28, no. 2, pp. 129-149, 2010.

[5] K. Charmaz, Constructing grounded theory. Sage, 2014.

[6] L. McCall, "The complexity of intersectionality," in Intersectionality and Beyond: Routledge-Cavendish, 2008, pp. 65-92. 